\title{
Words on the Street: Selling Small Printed 'Things' in Sixteenth- and Seventeenth-Century Venice
}

\author{
Laura Carnelos
}

In early modern Europe books were not only sold inside bookshops. Especially ordinary or everyday editions - those books printed and reprinted without any major changes to text or to typography, and the smallest works, such as histories, miracles, prayer books, news reports and songs - were often brought out on the street and sold around the city at the most populous places, such as squares, bridges and in front of churches. ${ }^{1}$ At the root of this strategy, and underpinning the relationship between these editions and the ways they were sold, there were-of course-commercial reasons: "more people, more money" was an obvious connection.

In this chapter I would like to propose a case study of the trade agents and distribution conditions of news and other small printed material within the sixteenth and seventeenth century Venetian Republic. Admittedly, the peculiar urban structure of Venice and the high concentration of printers and booksellers make it an exceptional case, even though it is possible to identify some shared characteristics with other European cities. However, Venice provides a useful example because of the important role it played within the European book market in the early modern age and because of the valuable and copious

1 Concerning London, see Bob Clarke, From Grub Street to Fleet Street. An Illustrated History of English Newspapers to 1899 (Aldershot: Ashgate, 2004); concerning Madrid, Jean-François Botrel, Libros, prensa y lectura en la España del siglo XIX (Madrid: Fundación Germán Sánchez Ruipérez, 1993), pp. 125-31; Ana Martínez Rus, 'El libro en la calle. De la venta ambulante a las ferias del libro', in Senderos de ilusión. Lecturas populares en Europa y América Latina (del siglo XVI a nuestros días), ed. Antonio Castillo Gómez and Verónica Sierra Blas (Somonte-Cenero [Gijón]: Trea, 2007), pp. 171-88; for Paris, Robert Darnton, 'An Early Information Society: News and the Media in Eighteenth-Century Paris', The American Historical Review, 105.1 (February 2000), pp. 1-27; Carl Goldstein, Print Culture in Early Modern France. Abraham Bosse and the Purposes of Print (Cambridge: Cambridge University Press, 2012), p. 44. On itinerant distribution networks see Jeroen L. Salman, Pedlars and the Popular Press. Itinerant Distribution Networks in England and the Netherlands 1600-1850 (Leiden: Brill 2013) and Not Dead Things. The Dissemination of Popular Print in England and Wales, Italy, and the Low Countries, 1500-1820, ed. Roeland Harms, Joad Raymond and Jeroen L. Salman (Leiden: Brill, 2013).

(C) LAURA CARNELOS, 2016 | DOI 10.1163/9789004277199_033

This is an open access chapter distributed under the terms of the Creative Commons Attribution-

Noncommercial-NoDerivatives 3.o Unported (CC-BY-NC-ND 3.o) License. 
documentation of the print trade preserved mainly in the State Archive of the city. Furthermore, by focusing on one city and analysing the changes undertaken in the industry over two centuries, we can show the diffusion conditions of printed material, the economic and political implications of the street trade, and the role played in urban life by the humblest figures who traded in books on the street.

Before presenting the Venetian case, a brief introduction is required. The development and diffusion of cheap literary forms between 1500 and 1700 was a European phenomenon. At various points during the sixteenth century each European country saw increasing numbers of imprints, particularly in pamphlet forms: political propaganda, Reformation and Counter-Reformation writings, reports about wars and other small works reflecting contemporary needs and anxieties, such as prophecies and accounts of monstrous births. ${ }^{2}$ If these imprints became a "powerful communicative tool" in early modern age, their success was doubtless due to the system of interconnecting posts and carriers linking the major European cities. ${ }^{3}$ If this existed on a large scale, the focus here is on the smaller, urban scale, and on the basis of the success of these forms within the confines of a city.

Street commerce played an undeniable role: a variety of mediators brought them directly under readers' eyes and into their hands by a variety of means. For a more concrete idea of these figures, the list of the usual agents for publishing written in 1663 in England by Roger L'Estrange, then Charles II's Surveyor of the Press, is useful. ${ }^{4}$ He mentioned printers, stitchers, binders, stationers, hawkers, mercury-women, pedlars ballad-singers, posts, carriers, hackney-coach-men, boat-men and mariners. Local differences excepted, this list can be taken as an example of how many different people were involved in the book trade and particularly in street commerce. To simplify,

2 Joad Raymond, Pamphlets and Pamphleteering in Early Modern Britain (Cambridge: Cambridge University Press, 2003); Mario Infelise, Prima dei giornali. Alle origini della pubblica informazione (secoli XVI e XVII) (Rome and Bari: Laterza, 2002); Ugo Rozzo, La strage ignorata. Ifogli volanti a stampa nell'Italia dei secoli XV e XVI (Udine: Forum, 2008).

3 Raymond, Pamphlets and Pamphleteering, p. 26; Paul Arblaster, 'Posts, Newsletters, Newspapers: England in a European system of communications', in News Networks in Seventeenth-Century Britain and Europe, ed. Joad Raymond (London: Routledge, 2006), pp. 19-34. See also Lodovica Braida, 'Le commerce du livre entre Genève et l'Italie au XviıIe siècle: agents, obstacles, pratiques', in L'Europe et le livre. Réseaux et pratiques du négoce de librairie $X_{V I}{ }^{e}-X I X^{e}$ siècles, ed. Frédéric Barbier, Sabine Juratic and Dominique Varry (Paris: Klincksieck, 1996), pp. 279-307.

4 Raymond, Pamphlets and Pamphleteering, p. 55. 
we can distinguish retail booksellers working at stalls or shops from mobile retailers, who carried imprints by hand or in containers such as baskets or bags, moving on foot or on horseback inside and outside cities and villages. We can look at the case of Venice to understand exactly how such an urban network functioned.

The first records describing the relationship between printing and the preferred distribution channels in Venice date back to the beginning of the sixteenth century, when the Senato (one of the major Venetian institutions which, among other tasks, supervised the book market) took several important decisions in an attempt to control the production and the diffusion of printed material. In 1517 the Senato decided that in the interests of a free and competitive market only new works, never printed within the Venetian Republic, could be subject to a privilege. ${ }^{5}$ All other imprints were freely printable by everyone once permission to print or sell them had been obtained from the Consiglio dei Dieci (another important institution watching over the security of the State). ${ }^{6}$ Some years later, in 1537 , the Senato determined that all works printed on less than ten folio sheets, known in Venice as cose minute ("small things"), could be printed on the lowest quality paper. ${ }^{7}$ Histories, miracles, prayer books, news reports, letters and songs were included in this category. This was not a minor decision because paper was the largest expense in printing books and, thanks to this law, printers and booksellers could keep the prices of the smallest, shoddiest imprints down. Therefore, as a consequence of less restrictive rules, such as those issued in 1517 and 1537, and because of the relative handiness and cheapness of the printing process, small publications became the most common material published and sold in the city.

A few years later, in the 1540 s, two problems arose that became a matter of concern for the Venetian government: the content of these imprints and the people involved in this commerce. Because of the ephemeral nature of such publications, usually consumed within a few days of printing, printers and booksellers often avoided asking for permission or did not wait to obtain it before printing or selling them. Without authorisation, the Senato could not

5 'Solum pro libris, et operibus novis, nunquam antea impressis, et non pro aliis': ASv (State Archive of Venice), Senato Terra, reg. 20, 1 August 1517, fos. 58v-59r.

6 Asv, Riformatori dello Studio di Padova, b. 364, 29 January 1527, in print.

7 Asv, Riformatori dello Studio di Padova, b. 364, 4 June 1537 in Pregadi, in print. Also in BMCV (Museum Correr Library), Mariegola MS IV 119, 4 June 1537 in Pregadi, fos. 2or-21v. In England, 'a pamphlet typically consisted of between one sheet and a maximum of twelve sheets, or between eight and ninety-six pages in quarto': Raymond, Pamphlets and Pamphleteering, p. 5. 
know exactly what circulated in the city and who printed or sold it. For this reason, in 1543 the Consiglio dei Dieci established public punishments for anyone caught printing or selling without permission "libri, et opere, pronostichi, historie, canzoni, lettere, et altre simil cose" ("books, and works, forecasts, histories, songs, letters and things like these") in the city, but especially on Rialto Bridge. ${ }^{8}$ Those guilty were to be whipped from St Mark's Square to Rialto Bridge and then imprisoned for six months. The punishment was even more severe for anyone discovered printing works with a false imprint on the title page: one year of prison, a fine of one hundred ducati and permanent banishment from Venice. Furthermore, on 30 December 1544, the Consiglio dei Dieci charged the Riformatori dello studio di Padova, the institution that dealt with schools and education in general, with revising all books before publication..$^{9}$ Only with the approval of the Riformatori would the Council grant a license for printing. Periodic inspections around the city, above all at St Mark's Square and on Rialto Bridge, would be carried out by the Riformatori to root out illicit behavior.

It is not known if these punishments ever came into effect. However, in 1549 the Consiglio dei Dieci decided that the foundation of a guild of printers and booksellers was the solution to the disorder and confusion in the printing trade. ${ }^{10}$ The guild of printers and booksellers (also called a 'school' or 'university') started to meet regularly and became effective after the 1570s, though only from the 1580 s did documentation concerning the guild become more systematic. Nevertheless, it is possible to discern something about the relationship between the 'small things' and their circulation around the city through some brief notes written in the main book of the guild, the Mariegola. Here we read that in 1565 it was decided that the sale of comedies, indecent and profane books was prohibited on holy days and Sundays. On these days only saints' books, Epistole et evangeli, prayer books, the lives of the saints, catechisms and other devotional works, could be sold under the portico of Rialto Bridge, the Drapparia; whereas small books about the saints, drawing paper and paintings of saints and other honest and religious subjects could

ASv, Riformatori dello Studio di Padova, f. 5, 12 February 1543, fos. 72r-73v. The law was reaffirmed in 1565: BMCV, Mariegola, 10 October 1565 , fos. $25 \mathrm{v}-26 \mathrm{r}$. On forecasts see Ottavia Niccoli, Profeti e popolo nell'Italia del Rinascimento (Rome and Bari: Laterza 1987), p. 29 .

9 BMCV, Mariegola, 30 December 1544 in Consiglio dei X, fos. 22v-23r.

10 Asv, Consiglio dei Dieci, parti comuni, f. 47, 18 January 1549. Asv, Riformatori dello Studio di Padova, b. 364, parti dell'Illustrissima Signoria di Venezia in materia delle stampe. Pubblicate sopra le Scale di Rialto, et di San Marco, in print. 
be vended along the Mercerie, the long route between Rialto Bridge and St Mark's Square.11

Evidently the Venetian government was trying to prevent printers and booksellers from printing and selling entertainments, songs and other non-devotional writings when potential customers would be more numerous. At all events, it is clear that the division between the Drapparia and the Mercerie was not absolute and that printers and booksellers often broke the law. For this reason, in 1566 more rules were established by the Consiglio dei Dieci concerning the licensing of books. Once obtained, every license was to be registered by the institution of the Esecutori contra la bestemia and a copy of every work printed was to be given to the Riformatoriallo Studio diPadova. The reason why more rules were imposed is because many printers were obtaining permission and subsequently altering the text—adding notes, making corrections, even introducing whole pagesbefore printing and stating con licenza ("with permission") on the title page, when permission for the text as actually printed had not been obtained. ${ }^{12}$

Despite these measures, designed to control short publications in particular, the emergent market of news, which rapidly expanded in printed and manuscript form, could not be suppressed. Two factors in particular may have contributed to the development of this trade: the need for more information, fostered by the sequence of natural disasters and the wars undertaken by Venice; and the great number of the newly unemployed who started dealing in these inexpensive and easy-to-find products..$^{13}$

11 вмCV, Mariegola, 1565, fo. 42r. They are pictures of saints, the booklet Epistole e vangeli (the most famous version edited by Remigio Nannini came into circulation in 1567, Laura Carnelos, I libri da risma. Catalogo delle edizioni Remondini a larga diffusione (1650-1850) (Milan: FrancoAngeli, 2008), n. 163), holy books, bibles and histories and saints' lives. Somebody selling these histories and almanacs was known in Venice as a 'storiaro': Giuseppe Boerio, Dizionario del dialetto veneziano (Venice: Reale tipografia di G. Cecchini, 1856), ad vocem "quel da l'istorie".

Asv, Riformatori dello Studio di Padova, b. 364, parti dell'Illustrissima Signoria di Venezia in materia delle stampe. Pubblicate sopra le Scale di Rialto, et di San Marco, in print; Asv, Riformatori dello Studio di Padova, b. 364, 28 June 1569 in Consilium X cum additione.

13 Paolo Preto, 'Le grandi paure di Venezia nel secondo '5oo: le paure naturali (peste, carestie, incendi, terremoti)' and 'Le grandi paure di Venezia nel secondo '500: la paura del tradimento e delle congiunture', in Crisi e rinnovamenti nell'autunno del rinascimento a Venezia, ed. Vittore Branca and Carlo Ossola (Florence: Leo S. Olschki, 1991), pp. 177-92 and 193-204. Concerning the agricultural crisis and the problem of the poverty in early modern age see Bronisław Geremek, La pietà e la forca. Storia della miseria e della carità in Europa (Rome-Bari: Laterza, 2001). 
The sale of written news was repeatedly prohibited by the Consiglio dei Dieci at least after ${ }^{1567}$, but without much force. ${ }^{14}$ Luigi Groto's works show the effect of news echoing around the city, bringing new people into writing and printing. ${ }^{15}$ Groto was a blind man from Adria, also called cieco di Adria (1541-85), who was appointed as public orator representing his city on official occasions and who was sent for this purpose to Venice to celebrate the elections of the Doge (its highest political office) from 1556 until his death. In 1572 Groto edited the Trofeo della vittoria sacra, ottenuta dalla Christianissima Lega contra i turchi nell'anno MDLXXI, a collection of verses about the Venetian victory against the Turks in 1571 dedicated to Monsignor Giambattista Campeggi, the bishop of Majorca. In the advice to the readers he wrote: "mi diedi a raccoglier tutte le rime composte sovra questa celeste vittoria, che di mattino in mattino uscivano a stampa, o di giorno, in giorno ivi erano mandate a penna per formarne uno intero, e ordinato volume" ("I started to gather together all the verses composed about this serene victory which morning by morning were printed or, day by day, were sent in manuscript form to print shops to be included in a whole orderly volume"). ${ }^{16}$

The 1571 victory caused a wave of news, letters and verses in Venice, quickly written and quickly spread around the city both in manuscript and in printed form. In fact, Groto's Trofeo was not the only collected work. The blind man of Adria probably was inspired by the initiative of the printer Giorgio Angelieri who published four volumes of verses about the 1571 victory between 1571 and 1572, followed by two volumes by the printer Sebastiano Ventura in $1572 .{ }^{17}$ Even

\footnotetext{
14 Infelise, Prima dei giornali, p. 154, no. 9.

15 See Valentina Gallo, 'Groto, Luigi', Dizionario Biografico degli Italiani, 60 (2003).

16 For Mons. Giovanni Battista Campeggi, bishop of Maiorca, see Adriano Prosperi, 'Campeggi, Giovanni Battista', Dizionario Biografico degli Italiani, 17 (1974). Trofeo della vittoria sacra, ottenuta dalla christianissima lega contra i turchi nell'anno MDLXXI ... con diverse rime, raccolte, e tutte insieme disposte da Luigi Groto cieco di Hadria ... In Venetia, appresso Sigismondo Bordogna et Franc. Patriani, [1572], ustc 834754, fo. †3v. See also Rozzo, La strage ignorata, p. 166.

17 Raccolta di varii poemi latini, e volgari: fatti da diuersi bellissimi ingegni nella felice vittoria reportata da christiani contta [sic] Turchi. In Venetia, appresso Giorgio Angelieri, 1571, USTC 804919. Raccolta divarii poemi latini, e volgari:fatti da diversi bellissimi ingegni nella felice vittoria riportata da christiani contra turchi. Parte prima [-terza]. In Venetia, presso Giorgio Angelieri, 1572. USTC 805038 Raccolta di varii poemi latini, greci, e volgari. Fatti da diversi bellissimi ingegni nella felice vittoria riportata da Christiani contra Turchi alli VII d'ottobre del MDLXXI. Parte prima [-seconda]. Con la relatione di tutto il successo di Famagosta. Et i nomi de i Bassà, et capitani ch'erano nell'armata turchesca. In Venetia, per Sebastiano Ventura, 1572. USTC 801329
} 
if the circulation of news does not seem to have suffered unduly from the repressive laws, some care was taken, at least by Groto. In 1572 Groto published his public discourse to the doge Luigi Mocenigo with the addition of the news just received from Flanders and elsewhere in Florence. ${ }^{18}$ It is possible that a different place of publication (Florence instead of Venice) was used as a strategy to avoid censorship during a very awkward period.

To gain a more concrete idea about how many printers and booksellers were working in Venice at this time, and how the two markets-the bookshop and the street-worked together, it is useful to examine the list of printers and booksellers made in 1567 on behalf of the Holy Office. Here 64 people were mentioned: 47 had a bookshop or printing shop ( 40 had a bookshop, 37 with a sign and three without, and seven had a printing shop; one of these seven also had a stall at St Mark's Square), and seventeen were pedlars selling books between Rialto and St Mark's Square. Of these seventeen, six were under the Rialto portico, three at the Fondaco dei Tedeschi, one on holy days along the Mercerie, one at San Salvador and six spread around St Mark's Square (on Ponte della Paglia, under the portici, near the churches of St Mark and San Basso; see Figures 32.1 and $3^{2.2}$ ). ${ }^{19}$ This means that, according to the Holy Office's list, in the year 1567 out of a total of 64 people, 47 (73.5\%) were fixed in a particular place and seventeen $(26.5 \%)$ were mobile retailers, but all of them were concentrated inside the areas of St Mark's Square and Rialto Bridge in a sort of overlapping subdivision of the territory. Shops were mostly located along the Mercerie, whereas mobile vendors could change their positions according to what and how they were selling.

18 Orazione di Luigi Groto cieco di Hadria, fatta al serenissimo principe Luigi Mocenigo, et alla Signoria di Vinezia. Con la lettera di monsignor Cornelio vescovo di Bitonto, al signor Marc'Antonio Colonna doppo la vittoria christiana, contra il turcho. Et la partita dell'armata da Messina, con la relazione di quanto è seguito a Castel nuovo, et gli avvisi di Fiandra di nuovo venuti, col numero delle vele che ha il gran turcho in essere quest'anno 1572. Et molti altri bellissimi avvisi d'altri luoghivenuti, come leggendo intenderete. In Fiorenza, a stanza di Domenico Celonaio, 1572. UstC 834753. On the Italian news network see Una città in piazza. Comunicazione e vita quotidiana a Bologna tra Cinque e Seicento. Biblioteca dell'Archiginnasio, Sala dello Stabat Mater 24 maggio-31 agosto 200o, ed. Pierangelo Bollettini, Rosaria Campioni and Zita Zanardi (Bologna: Compositori, 200o). ASv, Santo Uffizio, b. 156, 13 September ${ }_{1567}$, fo. $76 \mathrm{r}-\mathrm{v}$. See the maps in Laura Carnelos, 'Con libri alla mano'. Editoria di larga diffusione a Venezia tra '6 e '7oo (Milan: Unicopli, 2012), pp. 290-1, nos. 19-20. The map of Venice drawing by Lodovico Ughi in 1729 and published for the second time by Lodovico Furlanetto in 1739 represents how Venice looks like before the changes made in the nineteenth century, see Giocondo Cassini, Piante e vedute prospettiche di Venezia (1479-1855), (Venice: La stamperia di Venezia, [1982]), n. 72. 


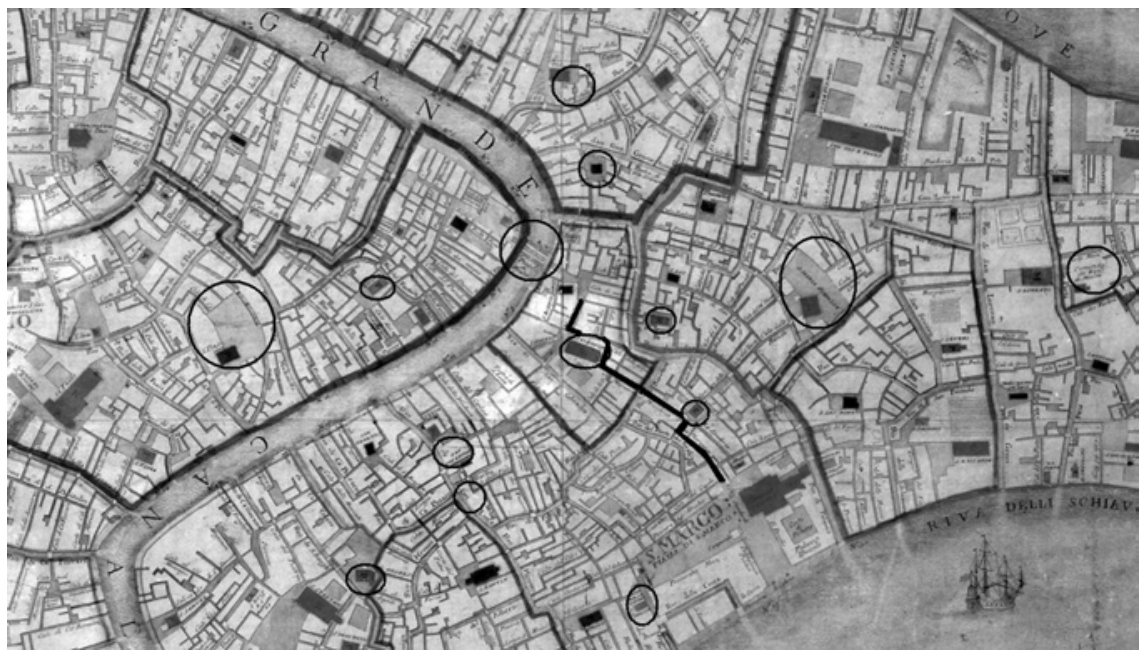

FIGURE 32.1 Printers and booksellers'shops in 1567

ARCHIVIO FOTOGRAFICO, FONDAZIONE MUSEI CIVICI, VENICE.

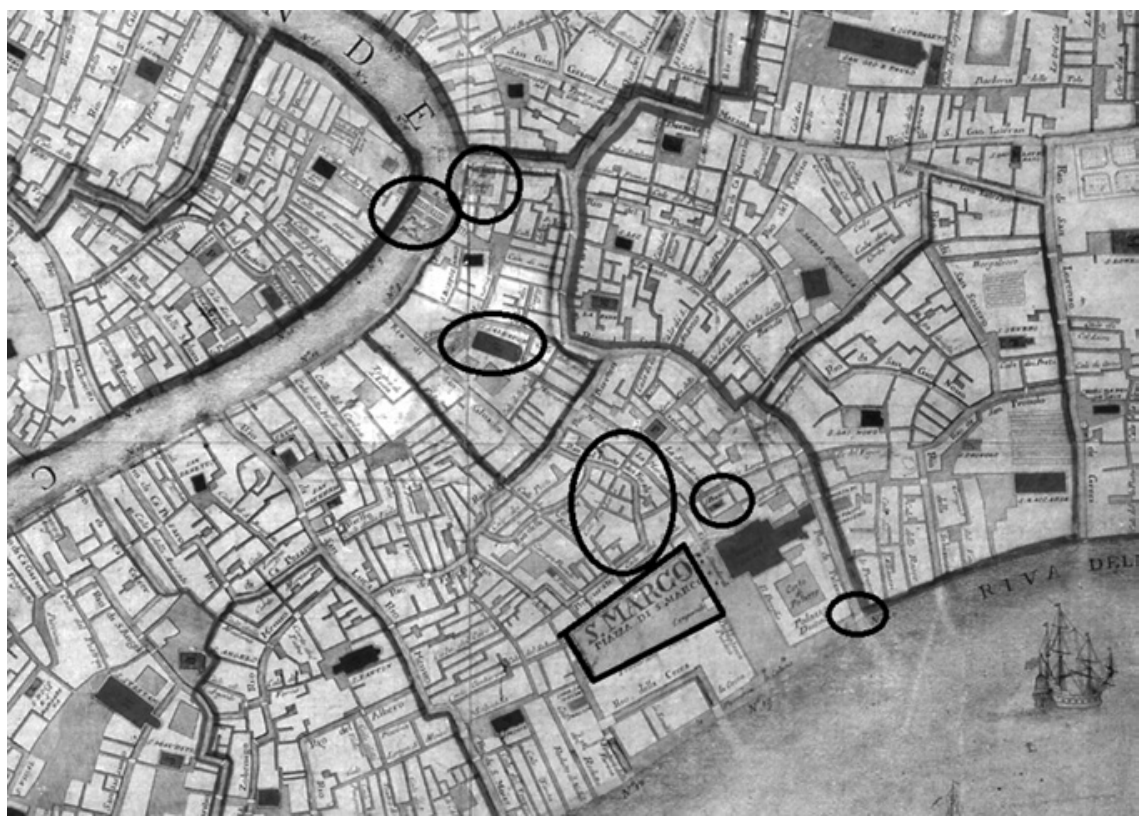

FIGURE 32.2 Distribution of pedlars in 1567

ARCHIVIO FOTOGRAFICO, FONDAZIONE MUSEI CIVICI, VENICE. 
In the same list by the Holy Office, two street stalls are mentioned. The centre of this kind of commerce was St Mark's Square, where fish, fruit, textiles and other products had been sold from stalls with the permission of the Procuratori di San Marco, the institution that had supervised the Square since the thirteenth century. ${ }^{20}$ Probably to prevent dirt and untidiness, this institution ordered in 1569 the removal of all the stalls, cases and boxes under the portico and the columns of the Ducal Palace and close to the bell tower of the Square. Despite this, some years later, the Holy Office and the guild of printers and booksellers found two booksellers selling on stalls in St Mark's Square. Moreover, one was found at San Moisé, behind the Square, and another under the portico of Rialto. ${ }^{21}$

During the first bubonic plague, in $1575^{-76}, 25^{-30} \%$ of the population died, and to re-populate the city the Senato invited people from the mainland to work in Venice. ${ }^{22}$ The consequence of this decision was a dualism: two authorities issuing different permissions for printing and selling news and books within the city. On the one side there was the Senato, which granted special licenses to non-guild members, and on the other side there was the guild of printers and booksellers, with its hierarchic structure and its rules. ${ }^{23}$

From this moment onwards, and even more after the second plague, in ${ }_{1628}-32$, when the Senato's action was re-affirmed, the guild never had the monopoly of the Venetian book-market. In fact, until the beginning of the nineteenth century, there were external workers, not subject to its laws, printing and selling in Venice. This is probably the reason why complete control of the book and news trade was impossible. As the Esecutori contro la bestemmia complained in 1596, histories, letters, news reports and other works, printed or falsely claimed to have been printed outside Venice against the law, were sold everyday in the Venetian squares (campi) and streets. ${ }^{24}$

20 ASv, Procuratori di San Marco. De Supra, b. P., 1 June 1296. On the management of churches, porticos and squares: Asv, Procuratori di San Marco. De Supra, b. P., 2 March 1315. Other laws concerning the selling on street stalls during the fourteenth and fifteenth centuries are written in ASv, Procuratori di San Marco. De Supra, b. P. On the management of San Mark's Square between 1293 and 1736: Asv, Compilazione leggi, b. 303, Piazza San Marco, 8 May 1634 .

21 ASv, Santo Uffizio, b. 156, 2 October 1571; 1 December 1571.

22 Paolo Preto, Peste e società a Venezia nel 1576 (Vicenza: N. Pozza, 1978).

23 More details in Laura Carnelos, 'La corporazione e gli esterni: stampatori e librai a Venezia tra norma e contraffazione (XVI-XVIII)', Società e storia, 130 (2010), pp. 657-88.

24 BMCV, Mariegola, 19 November 1596, fo. 4or. 
What consequences of the Senato's first invitation of 1576 can we highlight in the Venetian market? In St Mark's Square, arranging stalls, cases, boxes and ropes was still forbidden in 1580 . So, at the end of the sixteenth century, a retail market was not allowed there; only in 1608 was the law modified. ${ }^{25}$ That year the Procuratori decided that stalls and boxes could be placed inside the main square of the city, just not between the church and the standards. ${ }^{26}$ After 1608 , St Mark's Square became a recognised retail centre for books and other products. ${ }^{27}$ In contrast, on Rialto Bridge, the poorest members of the guild of printers and booksellers had been allowed since 1598 to sell religious books and pictures of saints on Sundays and on other holy days, when all the other shops should have been closed according to the rules of the Roman Church. ${ }^{28}$ However, in 1613, the Esecutori contro la bestemmia denounced some members of the guild who pretended to sell 'santi' (pictures of saints or small histories of them) while offering other histories and profane books on Sundays and other holy days. These booksellers waited for someone to pass in front of their shops (they were close to Rialto Bridge, so in a well-populated part of the city) strategically leaving the door ajar. Once a potential buyer was found, they would invite him into their shop to offer some small books or images. ${ }^{29}$

If the consequence of the first invitation of 1576 was making it increasingly difficult for the government to know who was selling and what was being sold around St Mark's Square and Rialto Bridge, after the second plague, in $1628-32$, and the second invitation by the Senato, the situation did not improve. On the contrary, the concentration of workers, both members and non-members of the guild, on the street likely grew. It was then that a new way of selling 'small printed things' started to be mentioned in the documents: from baskets. Easy

25 Asv, Procuratori di San Marco. De Supra, b. P, 9 April 1580. The law was reaffirmed by the Maggior Consiglio on 30 May 1582 and by the Procuratori di San Marco on 9 April 1584: Asv, Procuratori di San Marco. De Supra, b. P, 30 May $15^{82}$ and 9 April 1584. It is interesting that ropes are mentioned in the document. It is possible that drawings and paintings were sold hung on them as in Spain, whence the term literatura de cordel. On the literatura de cordel see, for example: Jean-François Botrel, 'La littérature de cordel en Espagne. Essai de synthèse', in Colportage et lecture populaire. Imprimés de large circulation en Europe XVI ${ }^{e}$ $X I X^{e}$ siècle. Actes du colloques des 21-24 avril 1991 Wolfenbüttel, sous la direction de Roger Chartier and Hans-Jürgen Lüsebrink (Paris: IMEC éditions, 1996), pp. 271-82. See the map of St Mark's Square in Carnelos, 'Con libri alla mano', p. 288, no. 15.

26 Asv, Procuratori di San Marco. De Supra, b. P, 9 November 1608.

27 See where were the stendards in Carnelos, 'Con libri alla mano', p. 288, no. 16.

28 Asv, Arti, b. 163, Atti II, 25 August 1598, fos. 4V-5r.

29 BмCv, Mariegola, 19 November 1596, fo. 4or. Asv, Arti, b. 163, Atti II, 26 August 1613, fos. 91-2. 
to find, handy and above all cheap, baskets could be filled with a good quantity of books and printed matter, more than could be carried by hand. The first reference to a cestariolo, as a seller with a basket was called in Venice, appears in a document of the Holy Office in $1535 .{ }^{30}$ Thereafter more people started to sell with a basket or other container (probably sacks and bundles), so many that it was forbidden in 1658 and restricted only to the poorest guild members. ${ }^{31}$ This sort of commerce was quite easy to pursue. It required no shop, no workers, no expenses, except in acquiring booklets to sell, and called for only limited observance of the law (because hiding everything in case of inspection was not too complicated). It also ensured a good income, because the pedlars sold their wares on the street, right in amongst potential buyers, and they offered the most popular genres and works. Costs and risks were reduced to a minimum. For this reason, the basket (or sack) trade was common not only among non-member workers: many guild members with a shop would send their sons or shop-boys to sell books and news around the city in order to increase their income. Beyond these cases, we can affirm that generally a cestariolo was a poor bookseller, a member of the guild, who was suffering from bad economic conditions, or a street vendor selling small printed items with the permission of the Senato or other special license.

To discover what those baskets or sacks usually contained, we can usefully examine contemporary illustrations. Probably the most famous image of a cestariolo is a French one: The colporteur. ${ }^{32}$ Interestingly this man carries a small underarm drum to draw the attention of the people around, and has some paper sheets on his hat, probably news, reports, histories, miracles (we do not know exactly what) in manuscript and printed form. Another relevant image of a cestariolo was engraved by Giuseppe Maria Mitelli who was inspired to a drawing by Annibale Carracci (Figure 32.3 ). ${ }^{33}$ Here small boards hang from the basket. Under the image is written "tavolette e libri per li putti", meaning tablets (or hornbooks) and books for children. This suggests that there was a relationship between this way of selling on the street and the books for

30 ASv, Santo Uffizio, b. 91, 1 March 1635, trial against Antonio Chiriachi. See also Asv, Inquisitori di Stato, b. 625, 25 September 1653, Defendi Prudentino. On the cestariol see Paolo Preto, Persona per hora secreta. Accusa e delazione nella Repubblica di Venezia (Milan: Il saggiatore, 2003), p. 96. Asv, Arti, b. 163, Atti IV, 22 January 1658, fo. 89v; Asv, Arti, b. 164, Atti viI, 25 May 1682, fo. 13 r.

32 Anonymous, École française, seventeenth century, oil on canvas, Paris, Musée des Civilisations de l'Europe et de la Méditerranée.

33 Achille Bertarelli, 'I gridi di piazza ed i mestieri ambulanti italiani dal secolo XVI al xx', Il libro e la stampa, 1.3 (1907), p. 16. 


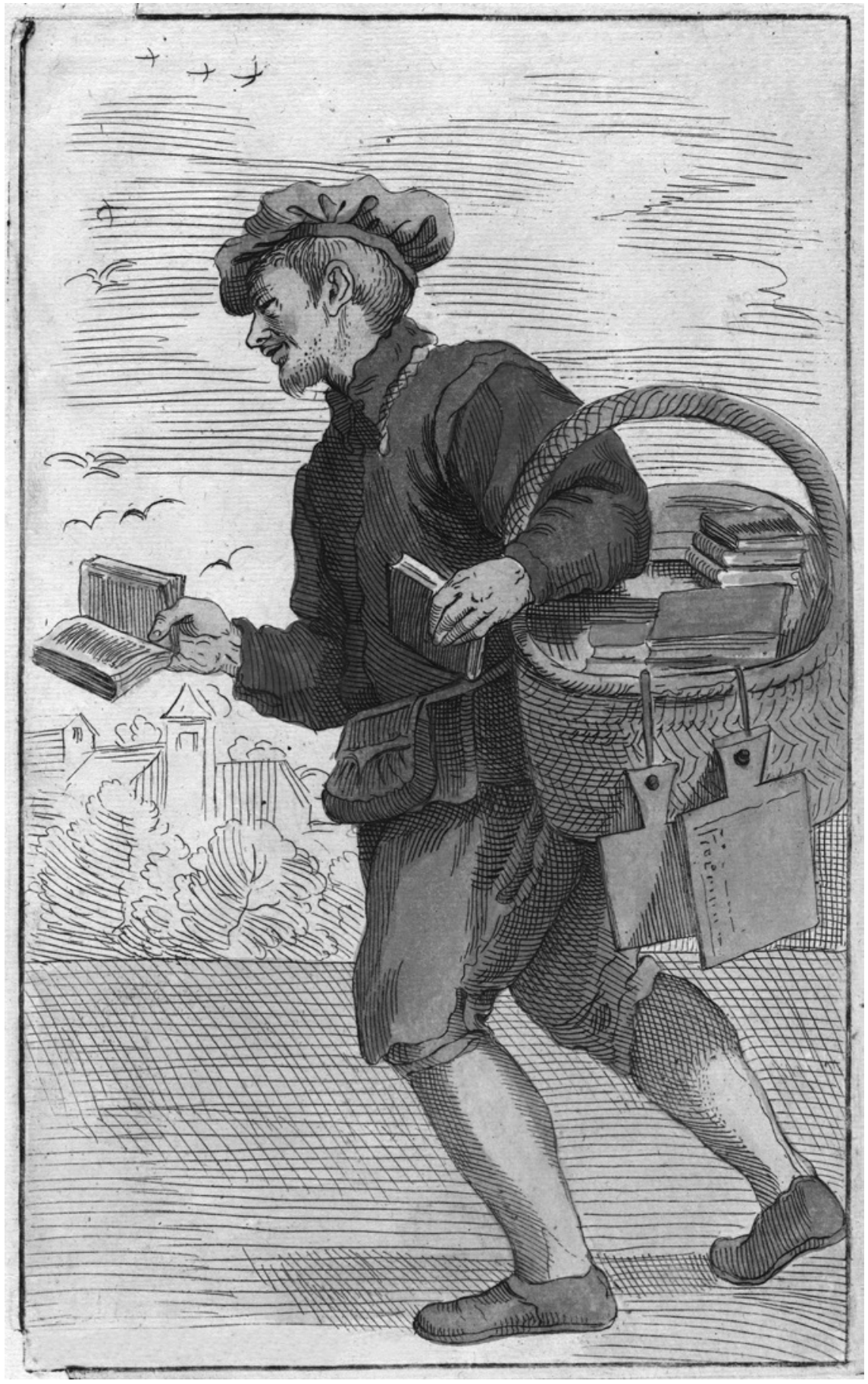

FIGURE 32.3 Tavolette e libri per li putti. Rome, 1647 PRIVATE COLLECTION, MILAN. 
children, mainly used inside the school, such as grammars, ABCs, prayer booklets, moral histories, Christian doctrine, spiritual exercises and mirrors, books on how to confess and pray, and leisure books.

If we look to London, and to The Cryes of the City of London (1687) by Marcellus Laroon, we find a representation a woman selling gazettes on the street using a sort of sack. ${ }^{34}$ The importance of this picture is threefold: the street vendor is a woman, she is selling gazettes, still an emerging genre, and she is using a sack instead of a basket. The presence of women selling printed material on the Venetian street is not documented, but their participation to the book and news trade cannot be ruled out. ${ }^{35}$

As just seen through the last three examples, it is difficult, or probably impossible, to attribute specific goods or selling modes to street vendors because they were extremely changeable. For instance, they could also sell other products together with books and news, such as pins, textiles and necklaces. ${ }^{36}$ However, it is a fact that these figures of book- and news-sellers appear much more in the documentation as the news market grew during the seventeenth century, and that they were concentrated inside the area extended from Rialto Bridge to St Mark's Square and San Moisé (behind the main square), exactly where hack writers were producing news, letters, and other small writings, more or less legally, on a stall or in a shop. ${ }^{37}$

Giuseppe Maria Mitelli himself engraved many pictures about the aversion to the mass of imprints and information which harassed people (Figure 32.4$).^{38}$ Even if it was more rhetorical than real, this means that the news network was rapidly expanding. ${ }^{39}$ In 1672 the Esecutori contro la bestemmia accused Venetian

34 Giles Mandelbrote, 'From the warehouse to the counting-house: booksellers and bookshops in the late 17th century London', in A Genius for Letters: Booksellers and Bookselling from the 16th to the 2oth Century, ed. Robin Myers and Michael Harris (Winchester: St Paul's Bibliographies, 1995), pp. 49-84.

35 Some information about women in typography can be read in Tiziana Plebani, Il 'genere' dei libri. Storie e rappresentazioni della lettura al femminile e al maschile tra Medioevo ed età moderna (Milan: FrancoAngeli, 2001), pp. 164-85.

36 Margaret Spufford, Small Books and Pleasant Histories. Popular Fiction and its Readership in Seventeenth-Century England (Cambridge: Cambridge University Press, 1989), pp. 116-2o. See also Commercio delle stampe e diffusione delle immagininei secolixVIII $e$ XIX. Trade and circulation of popular prints during the XVIII and XIX centuries. Bilderhandel und Bildverbreitung im 18. und 19. Jahrhundert, ed. Alberto Milano (Rovereto: ViaDellaTerra, 2008).

37 Infelise, Prima dei giornali, pp. 19-35.

38 See the pictures in Infelise, Prima dei giornali, pp. 208-11.

39 See also Venezia e la guerra di Morea. Guerra, politica e cultura alla fine del '6oo, ed. Mario Infelise and Anastasia Stouraiti (Milan: FrancoAngeli, 2005); Mario Infelise, 'Sistemi di 


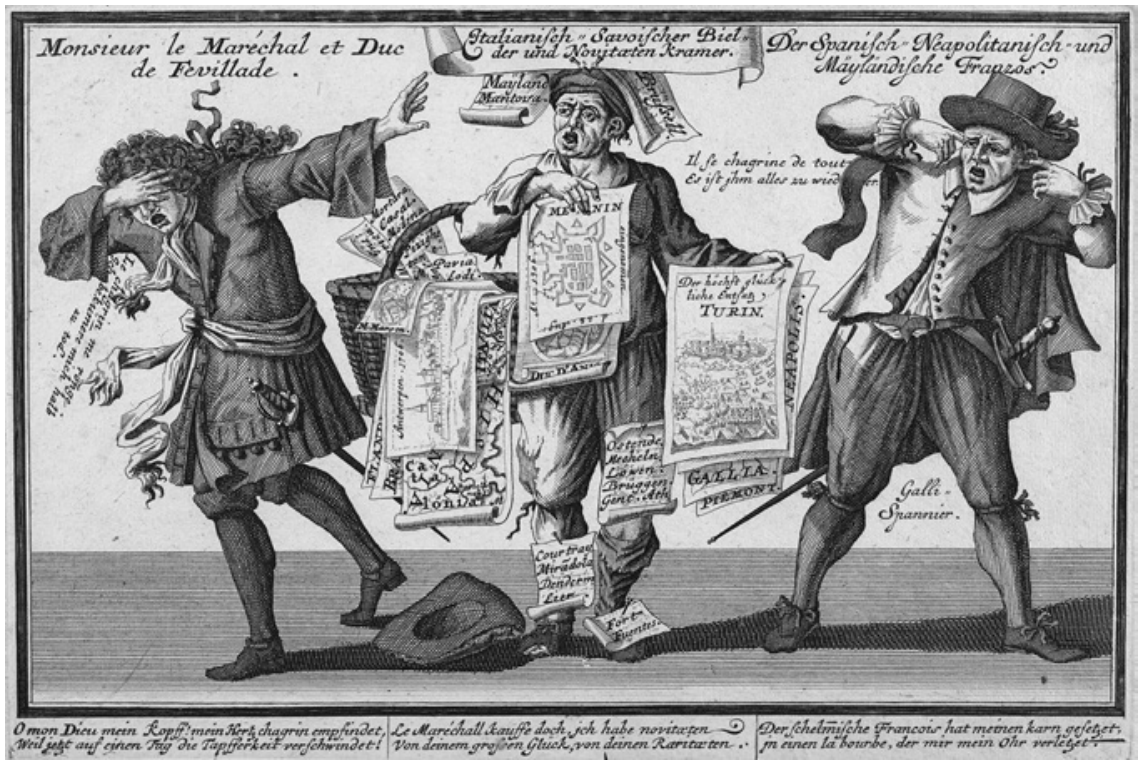

FIGURE 32.4 Italianisch Savoischer Bielder und Novitaeten Kramer. Germany, Augsburg (?), 1706. Rare German engraving inspired by the original Compra chi vuole avvisi di guerra, carte di guerra a buon mercato, a due bolognini l'una by G.M. Mitelli (1659?)

PRIVATE COLLECTION, MILAN.

printers of unlicensed selling of "books, songs, histories, laments, reports and other things" printed by them or by outsiders. For the first time, the 1672 accusation specified the involvement of mountebanks in this street commerce. ${ }^{40}$

Mountebanks usually sold printed works and other small items before or after their performances. For example, in 1571 the Procuratori di San Marco authorised a mountebank called 'Zanuol' to sing upon his stage, to sell histories, songs, perfume and red water (a particular mix) during the whole carnival. ${ }^{41}$ But, since the seventeenth century, mountebanks and other people who

comunicazione e informazione manoscritta tra '500 e '70o', in Scripta volant, verba manent: Schriftkulturen in Europa zwischen 1500 und 190o. Les cultures de l'écrit en Europe entre 150o et 19oo, ed. Alfred Messerli and Roger Chartier (Basel: Schwabe, 2007), pp. 15-35. On the power of these imprints see Filippo de Vivo, Information and Communication in Venice: Rethinking Early Modern Politics (Oxford: Oxford University Press, 2007), and Patrizi, informatori, barbieri. Politica e comunicazione a Venezia nella prima età moderna (Milan: Feltrinelli, 2012).

40 BмCv, Donà Dalle Rose, b. 341, fasc. II, 11 February 1672.

41 The special license was confirmed on 20 April 1571: Asv, Procuratori di San Marco. Chiesa, b. 4, reg. II, 14 February 1571, fo. 48; 20 April 1571, fo. 53. This source is mentioned in René Bernard Maria Lenaerts, 'La Chapelle de Saint-Marc à Venise sous Adriaen Willaert 
wanted to sell something or to set up a stage or a stall on St Mark's Square had to ask the permission of the bell ringer. This special license, later confirmed by the Riformatori dello Studio di Padova (in 1741), allowed mountebanks with or without a stage and other vendors, although they were not members of the guild of printers and booksellers, to deal in pamphlets, prayer books, songs and news and to sell them on St Mark's Square. ${ }^{42}$

Even if there was a commercial division within St Mark's Square between the Square (Piazza), where booksellers and mountebanks could set up their stalls and stages, and the small Square (Piazzetta), dedicated to all the other figures and sellers, the only image we have representing a book stall at St Mark's Square shows us another reality. In the picture (oil on canvas) entitled $L a$ piazzetta e la libreria painted by Luca Carlevarijs (1663-1730, Ashmolean Museum, Oxford) at the end of seventeenth century, we can see a book stall at the Piazzetta, close to the bell tower. Some small imprints, probably booklets and news reports, are displayed on a sort of covered table. At one side, a man is reading a book seated on a small bench and leaning on a box probably containing other books.

The Carlevarijs painting well represents the strengthening of the news market during the second half of the seventeenth century. This phenomenon is closely connected with the development of the service industry between the 1600 s and 1700s. Tourism started to grow and new structures were built: coffee houses, taverns and inns were launched mainly within the Rialto-St Mark's area and become soon part of a tangled web of gossip and news. ${ }^{43}$

On the subject of street vendors of books and news, another category of sellers needs to be mentioned: the blind men. In order to distinguish themselves from the false mendicants on the street, since the late Middle Ages the most needy blind people gathered together in specific brotherhoods, created by them and for them, in many Italian cities. One of the earliest charitable associations for the blind was established precisely in Venice in 1315 and for

(1527-1562). Documents inédits', Bulletin de l'Institut historique belge de Rome, 19 (1938), pp. $205^{-55}$.

43 On coffee-houses see Filippo Maria Paladini, 'Sociabilità ed economia del loisir. Fonti sui caffè veneziani del XVıII secolo', Storia di Venezia-Rivista, 1 (2003), pp. 153-281. On Venetian gossip see Alexander Cowan, 'Gossip and Street Culture in Early Modern Venice', in Cultural History of Early Modern European Streets, ed. Riitta Laitinen and Thomas V. Cohen (Leiden: Brill, 2009), pp. 119-39. On the circulation of ideas see Federico Barbierato, Politici e ateisti. Percorsi della miscredenza a Venezia fra Sei e Settecento (Milan: Unicopli, 2006). 
over two centuries it was located in the political centre of the city, at St Mark's church. In 1595, because of the confusion and disorders of the blind brethren inside the church, the Venetian government decided to move its seat to the nearby San Moisé. The brotherhood remained there-perhaps it is not a coincidence that they were close to news writer shops and stalls - until the beginning of the nineteenth century. ${ }^{44}$ The brethren used to beg at the entrances of churches and house-to-house, receive rent from some buildings the company owned in Venice and organise parades around the city to pick up the money collected in specific boxes inside churches. With the diffusion of the printing press, they started offering small ephemeral publications while singing or reciting their usual orations on the street. This small commerce likely expanded in the ensuing centuries. In fact, during 1700 , Venetian blind brethren also travelled around the Veneto region bringing small printed works in bags in order to increase the handouts. ${ }^{45}$ Even if the Venetian fraternity was not granted privileges to sell certain types of printed matter, such as news and prayer booklets, as the pious confraternities of blind men in Madrid and Lisbon were, ${ }^{46}$ it is possible that, during their trips around the Veneto region, blind men acted as colporteurs, peddling religious pamphlets as well as news.

The link between the blind men and the news trade is made more evident by studying those blind men who did not rely on charity. During the sixteenth and the seventeenth centuries, although suffering from partial or total blindness, some became famous street singers, others good performers. There was probably at least one blind singer in every city because they were known by their name and that of their home town, such as Bartolomeo cieco veronese, Cristoforo Scanello, il cieco di Forli, Catullo called 'Il Maritino', cieco of Murano (Venice), Giacomo, cieco of Verona, and so on. In one way or another they took part in the book and news market, entertaining a wide audience with songs and speeches on the most overcrowded streets and squares and frequently

44 Asv, Procuratori di San Marco. Chiesa, b. 4, reg. I, 30 April 1578, fo. 8 ov.

45 Asv, Scuole piccole e suffragi, bb. 155-6.

46 On Madrid: Jean-François Botrel, 'Les aveugles colporteurs d'imprimés en Espagne', Melanges de la casa de Velazquez, 9 (1973), pp. 417-82, and 'Des aveugles considérés comme mass-media', Melanges de la casa de Velazquez, 10 (1974), pp. 233-71; Juan Gomis Coloma, 'Intermediaros entre el texto y su público: la confradía de pobres ciegos oracioneros de Valencia', in Opinión pública y espacio urbano en la edad moderna, ed. Antonio Castillo Gomez, James S. Amelang and Carmen Serrano Sánchez (Somonte-Cenero, Gijón: Trea, 2010), pp. 301-17. Concerning Lisbon: Manuela D. Domingos, Livreiros de Setecentos (Lisboa, 2000), 55-65; André Belo, As gazetas e os livros. A Gazeta de Lisboa e a vulgarização do impresso (1715-176o) (Lisbon: Instituto de Ciências Sociais da Universidade de Lisboa, 2001), pp. 66-7. 
combining their exhibitions with the sale of ephemera publications. They could sing, like Paolo Briti cieco of Venice; act a history, like Cristoforo Scanello the blind man of Forlì or put news in verse form, as has been documented in Florence since the sixteenth century. ${ }^{47}$ However, not all blind men performed on the street. In fact, the case of Luigi Groto, cieco of Adria, is distinctly different. As we have already mentioned, he was a recognised scholar and a political mediator, but he testified as well the relevant role of news in sixteenth-century Venice by including them in some of his works. This was likely part of his strategy to participate in the information network which was gradually broadening inside the Venetian political and academic world.

As sketched in this brief chapter, in the early modern age, the heart of Venice was between St Mark's Square and Rialto Bridge, respectively the political and the economic centres of the city. The highest concentration of shops and workers in the whole of Venice was here, and it was at these two sites that the most important laws were posted and read aloud and that most of the ephemera were published and sold. Therefore, all the news (including new ideas, new books, and new laws) passed through these two areas, distributed by small vendors on shops or stalls, with baskets or sacks, or simply with their voice, gestures and writings, who played an important role in the widespread diffusion of information. Bridges, portici and the streets and squares in front of churches were the places usually occupied by the mobile retailers. By taking themselves to their customers, these mediators brought books and news to the street, where people could listen, perhaps learn by heart, or decide to buy and read, act, sing alone or to other people. That is to say that once on the street, and thanks to these smaller vendors, news circulation was barely under control.

47 Francesco Flamini, La lirica toscana del Rinascimento anteriore ai tempi del Magnifico (Pisa: T. Nistri, 1891), 159-61. On Paolo Briti and other blind men: Carnelos, 'Con libri alla mano', pp. 215-25. 